CURRENT RESEARCH JOURNAL OF PEDAGOGICS 2(12): 115-118,

December 2021 DOI: https://doi.org/10.37547/pedagogics-crjp-02-12-23

ISSN 2767-3278

(C)2021 Master Journals

Crossref do) 81 Google

Accepted $18^{\text {th }}$ December, 2021 \& Published 23 th December, 2021

\title{
MUSIC TRADITIONS OF THE UZBEK PEOPLE
}

\section{Mushtariy Jamoldin Kizi Juraboeva}

Master, Namangan State University, Uzbekistan

Gulmira Odilovna Odilova

Master, Namangan State University, Uzbekistan

\section{ABSTRACT}

Opportunities and conditions for the real development of the art of folk music were achieved only after Uzbekistan gained its national independence. During this period, first of all, due to the process of understanding the national identity, the process of re-examining the national cultural heritage and returning it to its rightful owners intensified. Second, the disadvantages of the regulators were eliminated. Third, the further development of the Uzbek national music has become one of the important directions of state policy.

KEYWORDS: - People, independence, heritage, status, song, music, tradition, value.

\section{INTRODUCTION}

Enjoying the unique masterpieces of classical and Uzbek folk songs in the lessons of music culture is the key to the effectiveness of the lessons. Folk music teaches to sing the melodies correctly, to feel guilty. As stated in the State Education Standard, new intellectual approaches to the teaching process should be used, as well as more intellectual, thought-provoking questions.[1]

Determine tone, method, speed and expressiveness, volume, length, tone, direction and variable. Correct perception of sounds, differentiation of national instruments, vocals, soloists, accompanists, ensembles and orchestral performances

To be able to perform a piece of music fluently and pleasantly, to understand its structure, content, mood, character, pleasant and pleasant aspects. With the creative development of music, musical ability is an interdependent and interdependent process.

In the performance of the maqoms and their branches, although it is possible to say from a high or low curtain according to the sound range of the hafiz, the principles of the maqom's structure must be taken into account when recording, and the overall structure of the maqom system must be preserved. Even the 
CURRENT RESEARCH JOURNAL OF PEDAGOGICS 2(12): 115-118,

December 2021 DOI: https://doi.org/10.37547/pedagogics-crjp-02-12-23

ISSN 2767-3278

(C)2021 Master Journals

Crossref doi) 81 Google

Accepted 18 $8^{\text {th }}$ December, 2021 \& Published 23 th December, 2021

musical treatises of medieval Eastern scholars specifically mention the curtains on the oud strings, which form the twelve maqom lad sounders and the corresponding melodies and song lines.

At the same time, special attention is paid to the tonic, which begins the path of status. in the past, too, of course, the singer continued to perform maqom tracks by transposing them according to the possibilities of sound. But in music theory, their veils a Music and singing not only help their fans to combine spiritual wealth, moral and physical perfection, but also play an important role in the development of our national and cultural heritage. Music and singing develop in close connection with the history of fiction and literature. At the same time, the attitude or interest in the Uzbek language is growing.[2]

It would be useful for music teachers in schools to work with language and literature teachers to organize literature and music clubs, listen to and analyze classical songs, and increase students' vocabulary. Thus, the main direction of maqom, folklore and Uzbek folk songs, in addition to providing spiritual nourishment to people in general, is to help them to reach spiritual maturity, to do good to people, to equip them with knowledge and enlightenment, to be fair and just. is of great importance.

In particular, the richness of the content itself, and the folk songs performed together with the poems written in a simple and fluent language, will remain in the memory of the students. Because of the complexity of the maqom melodies and songs, it would be advisable for the teacher to first listen to and analyze the students from the less complicated "Soqiynoma" or "Ufori" tracks while listening to the music. Excerpts from these status tracks can be performed by the teacher himself or read aloud to the students using technical means.

Thus, if we gradually inculcate in the minds of the younger generation our status, melodies and songs, which are our great cultural heritage, we will be able to better understand our national culture and musical heritage, appreciate it in the future and build strong beliefs.

The science of music teaches a person spiritual maturity, establishes faith and pure love in the hearts, shares joy and sorrow with us, sympathizes with us on the way of life and helps us to achieve a high spiritual culture. is one of the important factors.

Uzbek national musical instruments have a thousand-year history and are very colorful. Archaeological excavations in the Central Asian republics and Uzbekistan have shown that Uzbek musical instruments are rich in cultural heritage and similar to the musical instruments used today.[3]

The rock carvings, caves, and murals depict modern flutes, flutes, and harps, as evidenced by the fact that not only peoples, but even musical instruments have passed through historical stages.

In introducing and teaching musical instruments to students in music culture classes, the teacher should have a deep understanding of the history of the instrument, its origins, and how it is played.

I would like to emphasize that this article is based on the use of historical and modern technological methods of introducing students to musical instruments. In the works of scholars living in the XIV century from the ancient musical instruments ud, chang, kanun, rubob, tanbur, damli instruments Nay, surnay, arganush: from stringed instruments dutor, gijjak, kobus, rudyana.

There is information about puffing instruments nayi anbon, chagona, rukhafzo, bolamon, shammon and others.

Over the centuries, as human beings have 
CURRENT RESEARCH JOURNAL OF PEDAGOGICS 2(12): 115-118,

December 2021 DOI: https://doi.org/10.37547/pedagogics-crjp-02-12-23

ISSN 2767-3278

(C)2021 Master Journals

Crossref do: 81 Google

Accepted $18^{\text {th }}$ December, 2021 \& Published 23 th December, 2021

become more perfect, musical instruments have become more sophisticated, and to this day, colorful melodies have come to the heart. Now, for example, the dutar's kadi-basti is made of mulberry and apricot trees, one end of which is connected to the heart, the other end to the tongue. It should be noted that the Uzbek masters of art Usmon Zufarov, master Khoji Axun, master Rahim Kosimov, master Mansur, master Sirojiddin Muhiddinov, master The mastery and service of Rixsikhon Khuzakhanov and others is great.[4]

Through the study of the history of folk singing and its unique works, love for the Motherland, mutual respect and the rules of morality encourage students to think independently through a debate lesson. The Arabs, who brought Islam to Central Asia in the VII century, were not left without the culture of our ancestors and music. By the IX-X centuries, Bukhara became a place of high art and science in the Samanid state. During this period, world-famous scientists, poets and musicians emerged.

Musical ability is the basis for the development of creativity. The focus on the creative activity of musical activity directly contributes to the future development of musical talent.

Under the influence of musical knowledge and creative processes, the creative development of the child is hampered by the development of students' musical literacy, and this quality has a positive effect on all types of musical activities. In order to increase the creative activity of students, it is important to keep in mind the following.

The musical creativity of the Uzbek people is very productive, its roots go back to ancient times. We have thought about this in our chapters above on the priceless power. In terms of its structure, different genres are interconnected, and with its various forms, it is still relevant today.
First of all, classical, professional music, ie maqom performance, is the highest example of performance in these areas. This example of performance, which brings out the heartaches of our people, as well as the rich artistic music culture from the depths of centuries, is the main link of our musical creativity, our musical culture.

Our master scholars, who have lived and worked in this ancient land for thousands of years, have brought the performances of maqom, both theoretically and practically, to the present day. This is a great spiritual and musical wealth of our people.

One of the second examples of international performance, a series of performances that have always embodied the characteristics of all the ceremonies that our people have breathed together, is the performance of folk oral folklore. The unique history of folklore performance, patterns of performance, local styles of performance are polished, and these patterns of performance, styles, polished on the example of their unique performers, are still loved and performed.

The example of these two musical works combines the genres of classical music and folklore, the performance features of folk art, the developed genres of songs and instruments, the genres of performance in the oral tradition.[5]

The performance of epics has a special place in the performance of folklore. In the nature of its performance, it consists of heroic epics, as well as examples of performances that embody the images of heroes dreamed of by the people in a heroic lyrical content, in which epic works-epics play an important role.

During the centuries-long dream of independence, we have been fortunate to restore the ancient national values, including a comprehensive study of our artistic and musical 
CURRENT RESEARCH JOURNAL OF PEDAGOGICS 2(12): 115-118,

December 2021 DOI: https://doi.org/10.37547/pedagogics-crjp-02-12-23

ISSN 2767-3278

(C)2021 Master Journals

Crossref dof 81 Google

Accepted 18 ${ }^{\text {th }}$ December, 2021 \& Published $23^{\text {th }}$ December, 2021

heritage and the enjoyment of it by our people. To this day, under the pressure of the former Soviet ideology, our unique national musical values, which have been neglected, almost forgotten in some declining forms, have begun to recover. The masterpieces of folk music, consisting of ancient local traditions, various rhetorical and musical works in the artistic direction, began to be sung at prestigious folk festivals, international festivals and celebrations of important dates. Independence Day is celebrated all over the country in Navruz celebrations.

It is known that maqoms (mugams, muqams) are central to the traditional oral professional music of the peoples of the East. This may explain the reasons for the formation of state bodies.

The appearance of maqoms on radio, television and concerts requires significant changes in the composition of performers, and one of the forms of traditional performance development is the diversity of the pronunciation of the word maqom, its essence and ambiguity. not only an external expression of a particular national language and other features, the word is associated with the musical content, intonationmelody, metro-rhythmic composition, principles of expansion of the subject and features of the structure of the whole series of maqoms in each nation. The variety of Uyghur twelve maqoms differs from that of Shashmaqom in principle.

Unlike Shashmaqom, the earliest part of the Uyghur muqams, the Nagma head, is improvised and is characterized by a metro-rhythmically disordered plural form. Nagma bashi is available in all types and local variants of Uyghur (Kashgar, Khotan) maqoms, usually accompanied by a single musical instrument (tanbur, sato, rubob, doira and other instruments by a singer). instrument).

Which instrument to use depends on the local option. This is followed by metro-rhythmically arranged melodies, which have their own characteristics in each local variant. In Azerbaijani mughams, the improvisation of the appropriate metro-rhythmic free development of melody comes first.

It is not difficult to see that the positions in the republics are similar to those in Iran or in the Arab East. It is known that the Iranian and Azerbaijani devices have a lot in common and in many respects are even the same. But at the same time, according to memoirs published under the editorship of Dr. M. Berkeshli, the series of Iranian machines is more complex than the series of Azerbaijani machines.

The second group of each maqom branch also includes a few poems that are sufficiently developed in terms of melody, but have a slightly different category.

In short, the musical culture of the Uzbek people has developed on the basis of its ancient roots. This music has been passed down from generation to generation and has reached us with its beauty and splendor. This is the true happiness of our people.

\section{REFERENCES}

1. Omonullaev D. "Music programs in secondary schools". -T.: Teacher, 1992-P.54

2. Nurmatov X., Norkhodjaev N., "Alphabet of Music" -T.: Teacher, 1992 - P.23

3. Odilov A., Lutfullaev A. Musical instruments "Dust". Tashkent, 2002. - P.5

4. Qosimov R. Musical instruments - "Ud". Tashkent, 2002. - P.46

5. Solomonova E. History of Uzbek music. $-\mathrm{T}$.: Teacher, 1992-P.65 